\title{
Impact of Celebrity Endorsement on Brand Conscious Consumers: A Case Study in Pakistan
}

\author{
Mahwish Rabia, Fatima Babar, Saliha Akram, Zunaira Arif, Rida Tanveer \\ Government College Women University Sialkot, Sialkot, Pakistan \\ Email: mahwish.rabia@gcwus.edu.pk
}

How to cite this paper: Rabia, M., Babar, F., Akram, S., Arif, Z. and Tanveer, R. (2019) Impact of Celebrity Endorsement on Brand Conscious Consumers: A Case Study in Pakistan. Open Journal of Social Sciences, 7, 191-205.

https://doi.org/10.4236/jss.2019.74016

Received: February 23, 2019

Accepted: April 13, 2019

Published: April 16, 2019

Copyright $\odot 2019$ by author(s) and Scientific Research Publishing Inc. This work is licensed under the Creative Commons Attribution International License (CC BY 4.0).

http://creativecommons.org/licenses/by/4.0/

\begin{abstract}
Celebrity endorsement of brands is gaining popularity in the Pakistani markets. Most Pakistani brands gain popularity if any celebrity advertises their products and gets the attention of consumers. There are multi-million industries in the World. Brands usually use celebrities in their advertisement to increase their sales and change the point of view of consumers, which positively impact on their buying behavior. This research focuses on the celebrity endorsement and its impact on the brand conscious consumers and on their point of views regarding the brands. A quantitative method is used. The data of 263 respondents are collected through questionnaire and the results are analyzed using SPSS (Statistical Software). The students of Govt. College Women University Sialkot have been selected as respondents to know their point of view regarding celebrity endorsement on brand conscious consumers. It is noticed that brands advertised by celebrities are more attractive than the brands that are not advertised by celebrities. Moreover, products advertised by celebrities show a positive relationship with the buying behavior of consumers and help in brand promotion.
\end{abstract}

\section{Keywords}

Celebrity Endorsement, Brand Conscious Consumers, Celebrity Advertisement, Reliability, Correlation Coefficient, Branded Products, Purchasing Power

\section{Introduction}

Celebrity is being treated as a role model in today's world. People are changing their lifestyle because of their favorite celebrity. This point of view creates a great impact on brand conscious consumers and increases the productivity of brands. Celebrities are not always creating any kind of effect on person's mind in terms of buying but mostly it gives a great perception about choosing the products. We 
always think if our favorite celebrity is using that product then we should also use the same product. Nowadays, showing celebrity with their products is the best method to inspire the consumers. The main aim of advertising the products with celebrity is to get high brand vision, concentration and curiosity. For this purpose, brands use celebrity with their products. The major aim of advertisement is to inspire consumers towards the products. Celebrity endorsement of brands is gaining popularity in the market. Brand is a type of product manufactured by company under a specific name. Brand is all about to create any association with the consumers, when it shows any characteristic of the brands. To make brand successful, the first need is to understand the desire of the consumers. Many people just think that brand is just a name or symbol but indeed, it has larger definition and scope. It is overall image of the product which attracts the heart and mind of consumers. The major aim of any brand is to create attention and curiosity in mind of consumers. Today almost every brand uses celebrity to advertise their products because it is the best way to convey their brand's information to the public in an effective and efficient manner. According to consumers purchase intention, advertisement plays a very important role. It becomes useful for the brands to use all the strategies to inspire consumers towards their offers by using different types of celebrities. Celebrities are those people who are well known to a large number of people. They have special uniqueness and features like magnetism, unusual standard of living that is not common in common people.

\section{Review of Literature}

Asraf et al., [1] studied the relationship between consumer buying behavior and other marketing variables namely advertisement, brand image, brand association and brand loyalty in footwear industry. Many countries have studied the impact of brands and its relationship with the consumer behavior. Now brand creates importance in mind of consumers like celebrity advertisement. This advertisement creates perception about the products and consumer expects many things from products before using it like brand image, brand association etc. Brand has greater impact on consumer buying behavior. Brand conscious consumers prefer branded products even in high prices. Dissanayake and Weerasiri [2] said that celebrity endorsement is a form of advertisement, advertise branded products, by a well-known person. The attractiveness and trustworthiness of celebrity endorsement increases the productivity of brand. Consumers get impressed by brands which are advertised by celebrities. The study includes $52 \%$ of male respondents while $48 \%$ females of the total sample. The results explained that males are little more exposed than females about celebrity endorsements. Adam and Hussain [3] said that in this modern era, the world of advertisement undergoes a change. From classical ways, it has converted to take a modern route. This modern route requires marketers to develop strategies to get brand exposure, attention, interest, desire and action and to make these strategies into success, mar- 
keters employ famous celebrities because celebrities have the power to create a greater impact on the consumer buying behavior. Many big brands make use of the concept of celebrity endorsement as a marketing communication tool. In this study, females of Karachi are a target population, 74\% housewife are interested to buy that commodities which are advertised by celebrities. Celebrities are often perceived as idols by many people want to follow their lead and try out those products which have the touch of celebrities to them as celebrities make them those products more desirable.

Kaur and Greg [4] explained that use of celebrity for endorsement of a brand is widely used marketing strategy. Celebrity endorsement has become a pervasive element of multibillionaire advertising industry. The study determined the youth point of view about the celebrity endorsement, $66 \%$ of the respondents fall within the age group of $19-22$ years, think that the advertisement of celebrities increased the brand recall rate and helps in recognition of the brand.

Gladson and Stella [5] examined the perception of Nigerian Consumers about the celebrity endorsement and its impact on brands. It was observed that the advertising is the most common and effective tool used in creating awareness and convincing consumers about the brand name. The study revealed that, from $34 \%$ of the respondents at $20-30$ age group, $23 \%$ purchase branded product more than once a day. Celebrities makes the product more attractive.

Shehzad et al., [6] concluded that brand plays an important role to boost up the economy of any country. Brand is only tool that can change the buyer's behavior. The purpose of this study is to examine and explore the brand name on consumer buying behavior on the university's students of Gujranwala, Faisalabad and Lahore. Before the actual study the researcher conducted a pilot study with 40 respondents. The male respondents were 62 percent while female respondents were 38 percent. Today people are more conscious about brand than the past. Brand attention can also effect on consumer decision. Malik et al., [7] examined the impact of brand image and advertisement on consumer buying behavior in the general public at Gujranwala city. A sample of 200 questionnaires was used in which 175 responses were collected within the period of one month. Among these respondents $90.9 \%$ respondents are single and $9.1 \%$ respondents were married. Findings show that brand image and advertisement have strong positive influence and significant relationship with consumer buying behavior. Study has depicted that teenagers in Gujranwala are more conscious about their social status, so they prefer branded products and advertisement effects their consumer buying behavior positively.

Miller and Allen [8] recommended that the endorsement relationship has involved celebrity as spokesperson. A celebrity appears in an advertisement and convey a message in form of advertised products to attract the consumers to buy their products. Actors, musicians or cricketers who appears on TV or in movies wear designer labels to support a brand. Celebrities change the perception of consumer towards brands. 
Esangbedo [9] realized that celebrity endorsement is a channel of brand communication in which a celebrity acts as the brand's spokesperson and endorses it. The brand claims about their position by his/her personality, popularity, status in the society. The purpose of the study was to determine the persuasiveness of celebrity endorsements on the purchase decisions of Roman University students aged 18 - 24. Over the years, the use of celebrity endorsers has increased exponentially and has become common practice among marketers. Hareem Zeb, et al., [10] examined Pakistani female consumer's buying behavior and understand the key factors of branded clothing which influence female consumer's involvement towards branded clothing. A survey was conducted from general female consumers aged between 20 - 35 to obtain empirical evidence by using questionnaire and statistical techniques. The results indicate that brands positively effects on females buying behavior. Four major brands have been mentioned in the research which is Chen One, Junaid Jamshed, Bareeze and Threads and Motifs. Female consumers possess strong positive attitude towards high level brand shows related to fashion clothing. Khasawneh and Hasouneh [11] determined the significant effect of brand names on the consumers behavior and a relation between the customer demographic profile and the extent to which people affected by the products having brand name. People consider, that branded products have more quality than non-branded products. Brand is a symbol of social status. Spry [12] summed up that celebrity endorsement is considered an effective tool for brand promotion. It leads to a favorable attitude towards endorsed brand. Product value is enhanced by brand name. It is also useful in building branded industry, influencing people towards product quality and uniqueness.

\section{Research Methodology}

\subsection{Celebrity Endorsement}

Celebrity endorsement is used to get attention of the consumer, by involving the specific celebrity in the advertisement would motivate people to get attention towards the products because this strategy increases the attention of consumers towards the branded products. The following figure elaborates it graphically.

Figure 1 defines the factors associated with celebrity endorsement. In fact, celebrity advertisement is, when a famous person uses their status to promote a product. The benefit of using a celebrity for advertisement is the ability to build brand awareness, brand quality, brand loyalty and brand name in a society which

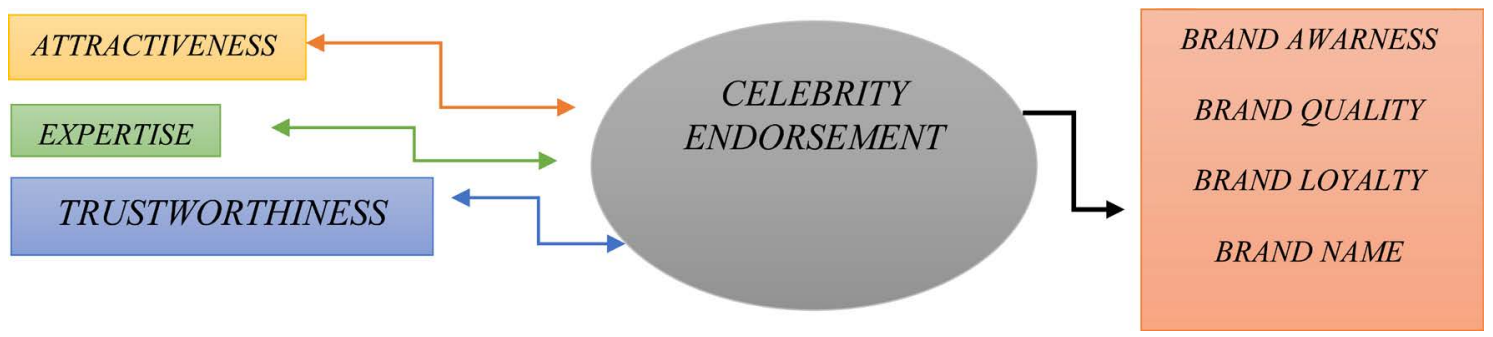

Figure 1. Factors associated with celebrity endorsement. 
allows the brand to achieve larger sales and profit. It makes a product more attractive. Brand conscious consumer become attracted because of the products advertised by celebrities that increase the knowledge about brand quality and reliability.

\subsection{Purpose of the Study}

The present study focus on assessing the point of view, from the students of Government College Women University Sialkot, Pakistan about how celebrity endorsement affects the brand conscious consumers. The reason behind it, is to know the influence of branded products on student's life and data is collected for the period from September to December 2018.

\subsubsection{Target Population}

All the students of Govt. College Women University Sialkot.

\subsubsection{Sampled Population}

Different departments of Govt. College Women University Sialkot.

\subsubsection{Method of Enquiry}

Questionnaire is used as a method of enquiry. It is designed by the author considering different variables according to celebrity endorsement and brand conscious consumers which affects the purchasing power (see Appendix).

\subsubsection{Sampling Technique}

Simple random sampling is used to choose the respondents.

\subsection{Determination of Sample Size}

In this research, the population of size 4725 is considered taking BS (Hons.) students. The representative part of the population is called sample. Using Yamane [13] formula given in Equation (1), where " $N$ " is the total population size and " $e$ " is the margin of error, a sample of 263 is determined from the given population. The procedure is given below:

$$
\begin{aligned}
& n=\frac{N}{1+N e^{2}} \\
& n=\frac{4725}{1+4725(0.06)^{2}} \\
& n=263
\end{aligned}
$$

\subsection{Statistical Methods}

The following statistical methods are used to analyze the data.

1) Reliability Analysis

2) Descriptive Statistics

3) Inferential Statistics

\subsection{Significance of the Study}

The significance of the study is: 
1) To analyze the perception of GCWUS students about the celebrity endorsement on brand conscious consumers.

2) To find out the relationship between celebrity endorsement and brand conscious consumers.

3) To analyze the students' favorite celebrity and brand.

4) To examine that advertisement of celebrity may increase the popularity of brand.

5) To analyze that branded products are used for a long time or not.

6) To analyze that discount on brands either increase or decrease the purchasing power of consumers.

7) To find out that either branded products are expensive or not.

8) To examine that products which are advertised by celebrities are reliable or not.

9) To examine that whether product sales rise because of celebrity advertisement.

\section{Results and Interpretation}

\subsection{Reliability Analysis}

"Reliability" is how well a test measures what it should. Table 1 represents the reliability analysis. A value of Cronbach's Alpha which will greater than 0.7 is acceptable. In the present study the value of Cronbach's Alpha is 0.521 because a small sample size is considered and by increasing the sample size the value of reliability statistic can be increased.

\subsection{Graphical Representation}

Figures 2-5 shows the graphical representation of different variables of brands.

Table 1. Reliability statistics.

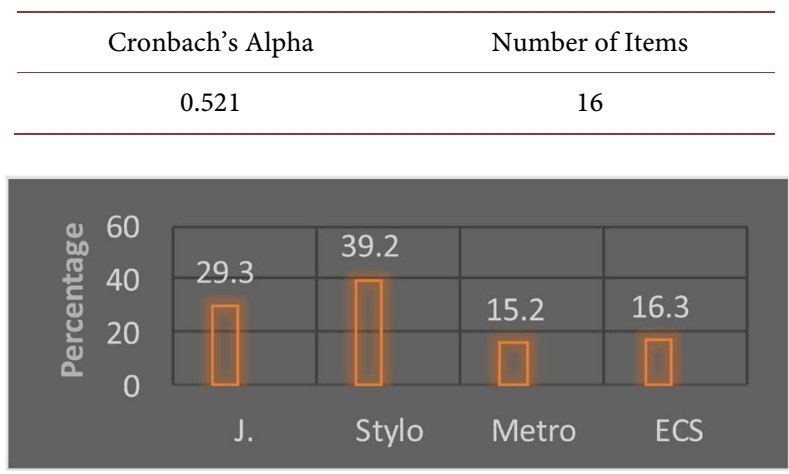

Figure 2. Favorite brand.

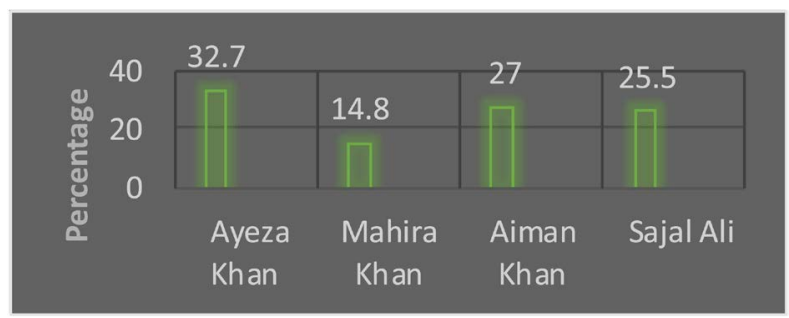

Figure 3. Favorite female celebrity. 
It illustrates that 29.3\% students like the brand-named J., 39.2\% like Stylo, 15.2\% students like the Metro and $16.3 \%$ like ECS. Figure 3 reveals that $32.7 \%$ student's favorite female celebrity is Ayeza Khan, $14.8 \%$ prefer Mahira Khan as favorite female celebrity, $27 \%$ student's favorite female celebrity is Aiman Khan and $25.5 \%$ student's favorite female celebrity is Sajal Ali. Figure 4 shows that $22.8 \%$ students like footwear, $60.8 \%$ like clothes, $7.2 \%$ like bags and $9.1 \%$ like perfumes to buy. Figure 5 represents the percentage of favorite male celebrity and according to results, 36.5\% students prefer Shahid Afridi, 33.5\% prefer Fawad Khan, 18.6\% prefer Faisal Qureshi and 11.4\% prefer Fahad Mustafa as favorite male celebrity.

Table 2 shows that $82.9 \%$ students notice the quality, $8.0 \%$ notice the price, $3.0 \%$ notice the endorsing celebrity and $6.1 \%$ notice the advertisement of the brand. Consumer satisfaction has a significant effect on brand loyalty. Branded products have good quality that effect consumer's satisfaction. In other words, branded products quality is better than local shops products. That's why, $82.9 \%$ people notice the quality of a brand.

Table 3 illustrates that $40.7 \%$ students strongly agree, $21.7 \%$ students just agree, $6.5 \%$ students have neutral point of view and $24.0 \%$ disagree and $7.2 \%$ strongly disagree to buy a brand if your favorite celebrity is endorsing it. According to results, mostly students are strongly agree to buy a brand if your favorite celebrity is endorsing it.

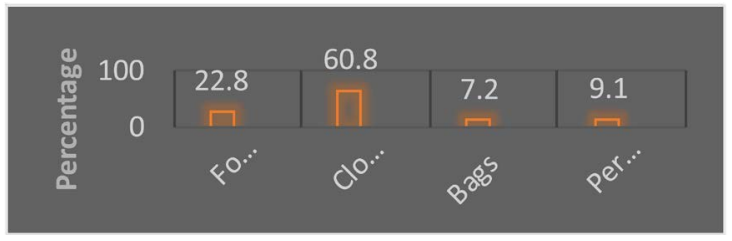

Figure 4. People more interested and want to buy.

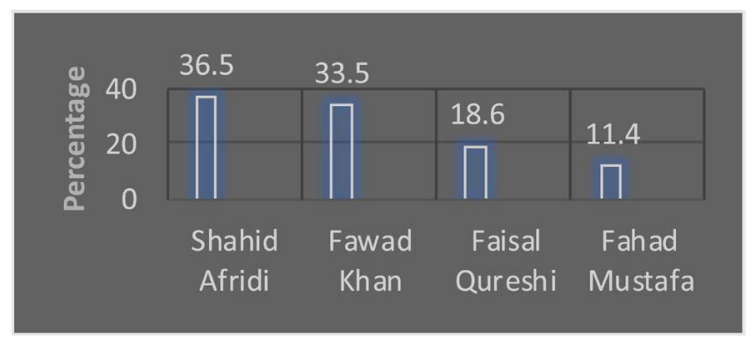

Figure 5. Favorite male celebrity.

Table 2. Frequency distribution when respondents notice a brand.

\begin{tabular}{cccc}
\hline Variable & Categories & Number & Percent \\
\hline & Quality & 218 & 82.9 \\
You notice a brand. & Price & 21 & 8.0 \\
& Endorsing Celebrity & 8 & 3.0 \\
& Advertisement & 16 & 6.1 \\
\hline
\end{tabular}


Table 4 demonstrates that $68.4 \%$ students think that celebrity advertisement helps in brand promotion, $16.0 \%$ think that celebrity advertisement do not help in brand promotion and $15.2 \%$ students not sure about either celebrity advertisement helps in brand promotion or not. These results depict that mostly people $(68.4 \%)$, agree that celebrity advertisement help in brand promotion because celebrities use their social status or fame to promote a product, which allows the brand to achieve larger sales and profits.

Table 5 shows different sources to get information about product. It represents that, $53.2 \%$ students watch TV ads, $22.1 \%$ search websites, $6.1 \%$ search favorite celebrity, and $18.6 \%$ visit point of sales. That is, mostly people watch Television ads (TV ads) to find information about products as Television (TV) is the most powerful medium for advertising.

Table 6 indicates that $45.62 \%$ students buy only branded products, $38.02 \%$ do

Table 3. Frequency distribution when respondents buy a brand if favorite celebrity is endorsing it.

\begin{tabular}{cccc}
\hline Variable & Categories & Number & Percent \\
\hline & Strongly agree & 107 & 40.7 \\
& Agree & 57 & 21.7 \\
Buy a brand if your favorite celebrity & Neutral & 17 & 6.5 \\
is endorsing it. & Disagree & 63 & 24.0 \\
& Strongly disagree & 19 & 7.2 \\
\hline
\end{tabular}

Table 4. Frequency distribution when celebrity advertisement help in brand promotion.

\begin{tabular}{cccc}
\hline Variable & Categories & Number & Percent \\
\hline $\begin{array}{c}\text { Celebrity advertisement help } \\
\text { in brand promotion. }\end{array}$ & Yes & 180 & 68.4 \\
& No & 42 & 16.0 \\
\hline
\end{tabular}

Table 5. Frequency distribution for sources of product information.

\begin{tabular}{cccc}
\hline Variable & Categories & Number & Percent \\
\hline & TV. ads & 140 & 53.2 \\
Sources of product information. & Websites & 58 & 22.1 \\
& Favorite celebrity & 16 & 6.1 \\
\hline
\end{tabular}

Table 6. Frequency distribution for respondents buying behavior.

\begin{tabular}{cccc}
\hline Variable & Categories & Number & Percent \\
\hline & Yes & 120 & 45.62 \\
Buy only branded products. & No & 100 & 38.02 \\
& Sometimes & 43 & 16.35 \\
\hline
\end{tabular}


not buy branded products and $16.35 \%$ buy sometimes branded products. The results portray that consumers mostly buy branded products, but they do not buy only branded products, the reason behind is, branded products are expensive as compare to local products.

Table 7 demonstrates that $46.4 \%$ consumers persuade to purchase a product through social media, $25.1 \%$ buy at point of sales, $21.3 \%$ agrees that TV is a mean of advertisement, which influence people and $7.2 \%$ attracts by magazine to purchase a product. Television (TV) is a powerful medium of advertising but now a day's youth uses social media like Facebook, Instagram, Twitter etc. social media helps to endure brand. Brand management design official page of their brand and upload the product pictures and discount on old items, which attracts the brand conscious consumers more than TV ads.

Table 8 shows that $3.8 \%$ students like the hair of favorite celebrity, $25.1 \%$ like look of favorite celebrity, $15.2 \%$ students like lifestyle of favorite celebrity and $55.9 \%$ students like all of them (Hair, Look and Lifestyle) of favorite celebrity. Many people, especially teenagers, dream of being a celebrity. They wish that they look beautiful like their favorite celebrity. If celebrity is well-looking, then this factor attracts the consumer more to buy that specific product.

Table 9 shows that 30\% students use branded products for one year, 14.8\% use branded products for two years and 55.1\% students use branded products for a long time. Branded products can be used for long time because branded

Table 7. Frequency distribution for means of advertisement.

\begin{tabular}{cccc}
\hline Variable & Categories & Number & Percent \\
\hline $\begin{array}{c}\text { Means of advertisement persuades } \\
\text { people to purchase a product. }\end{array}$ & Social media & 122 & 46.4 \\
& Point of sales & 66 & 25.1 \\
& TV & 56 & 21.3 \\
\hline
\end{tabular}

Table 8. Frequency distribution for what respondents like in favorite celebrity.

\begin{tabular}{cccc}
\hline Variable & Categories & Number & Percent \\
\hline Like in your favorite celebrity. & Hair & 10 & 3.8 \\
& Look & 66 & 25.1 \\
& Lifestyle & 40 & 55.9
\end{tabular}

Table 9. Frequency distribution how long respondents use a branded product.

\begin{tabular}{cccc}
\hline Variable & Categories & Number & Percent \\
\hline & One year & 79 & 30.0 \\
You use branded products. & Two years & 39 & 14.8 \\
& For a long time & 145 & 55.1 \\
\hline
\end{tabular}


products are expensive and have good quality that's why they can be used for long time.

Table 10 shows that $17.9 \%$ students think that products advertised by celebrities are reliable, $24.0 \%$ students think that product are advertised by celebrities are not reliable and $58.2 \%$ students are not sure that products advertised by celebrities are reliable or not, because sometimes products do not fulfill the consumer demand. Most important, many consumers trust on the quality of branded products, so they buy the products at any higher price, because brands provide guarantee material.

Table 11 designates that $76.0 \%$ students think that some products sales dramatically rise because of celebrity advertisement and $24.0 \%$ students think that some products sales are not dramatically rise because of celebrity advertisement. Celebrity endorsement has generally seen as desirable option for brands to increase awareness, built credibility and promote products. Brand conscious consumers are seems to be attracted more from celebrity endorsement products than non-celebrity endorsement products that effect the sale of branded products sales.

Table 12 illustrates that if a brand owner offers discount on products, then the purchasing power of consumer increases $(82.5 \%)$ while $3.4 \%$ think that it decreases and $14.1 \%$ think that it is normal. It is clearly shown from results that mostly people think that during money off period purchasing power of consumer increases. When the brand owner offers discount on products, brand conscious consumers buy more products like clothes, bags, footwear and perfumes etc. because sometimes consumer do not buy their favorite products at high price, so it acts as an opportunity to buy branded product at lower price.

Table 10. Frequency distribution for Products advertised by celebrities are reliable.

\begin{tabular}{cccc}
\hline Variable & Categories & Number & Percent \\
\hline Products advertised by celebrities are reliable. & No & 147 & 17.9 \\
& Not sure & 53 & 24.0 \\
\hline
\end{tabular}

Table 11. Frequency distribution for rise in products sale because of celebrity advertisement.

\begin{tabular}{cccc}
\hline Variable & Categories & Number & Percent \\
\hline $\begin{array}{c}\text { Product sales dramatically rise because } \\
\text { of celebrity advertisement. }\end{array}$ & Yes & 200 & 76.0 \\
\hline
\end{tabular}

Table 12. Frequency distribution when discount on products, increase the purchasing power of consumer.

\begin{tabular}{cccc}
\hline Variable & Categories & Number & Percent \\
\hline & Increased & 217 & 82.5 \\
$\begin{array}{c}\text { Brand owner offers discount on products, } \\
\text { then the purchasing power of consumer is. }\end{array}$ & Decreased & 9 & 3.4 \\
& Normal & 37 & 14.1 \\
\hline
\end{tabular}


Table 13 depicts that $91.6 \%$ students think that branded products are expensive, and $8.4 \%$ students think that branded products are not expensive. If someone compares branded products to non-branded products then it can be noticed that brands uphold many methods of manufacturing, styling and functionality for higher quality

\subsection{Correlation Coefficient}

To check the relationship between different attributes correlation coefficient is calculated. In Table 14, the value of correlation coefficient $(\mathrm{r}=0.217$, $\mathrm{P}$-value $=$ 0.01 ) shows the significant relationship between, sources of product information and celebrity advertisement. That is, if the sources of product information increase then celebrity advertisement also helps in brand promotion in the same direction. In other words, if the sources of product information (TV ads, websites, favorite celebrity and point of sales) rises then consumers will be more attracted to this product information and will buy product of that specific brand that help in brand promotion. Similarly, the correlation coefficient $(r=0.362)$ shows that correlation between the sources of product information and the product sales is significant $(\mathrm{P}$-value $=0.009)$. That is, if sources of product information rise then products sale will be dramatically increases. Moreover, the correlation coefficient $(r=0.260)$ illustrates that a strong positive relationship exists between the celebrity advertisement and discount on products. That is, celebrity advertisement and discount on products affects the sales of items. It illustrates that if celebrity advertise the products (branded items) and, at the same time the owner, offers discount on products then the purchasing power of consumers will increase. Meanwhile, the correlation coefficient $r=0.216$ also demonstrates strong positive relationship between what people like in favorite celebrity

Table 13. Frequency distribution representing branded products are expensive.

\begin{tabular}{cccc}
\hline Variable & Categories & Number & Percent \\
\hline & Yes & 241 & 91.6 \\
Branded products are expensive. & No & 22 & 8.4 \\
\hline
\end{tabular}

Table 14. Relationship between variables through correlation coefficient.

\begin{tabular}{ccccc}
\hline Attributes & $\begin{array}{l}\text { Correlation } \\
\text { Coefficient }\end{array}$ & P-value & Conclusion \\
\hline Sources of product information and Celebrity advertisement & $0.217^{* *}$ & 0.000 & Significant \\
Sources of product information and products sales & $0.362^{* *}$ & 0.009 & Significant \\
$\begin{array}{c}\text { Celebrity advertisement and discount on products } \\
\begin{array}{c}\text { What people like in favorite celebrity and products sales } \\
\text { because of celebrity advertisement. }\end{array}\end{array}$ & $0.260^{* *}$ & 0.000 & Significant \\
$\begin{array}{c}\text { Favorite male celebrity and means of advertisement } \\
\text { persuades to purchase a product. }\end{array}$ & $-0.136^{*}$ & 0.028 & Significant \\
\hline
\end{tabular}

${ }^{*}$ Correlation is significant at the 0.01 level (2-tailed). ${ }^{*}$ Correlations is significant at the 0.05 level (2-tailed). 
and product sales because of celebrity advertisement. This positive correlation shows that if people like hair, look and lifestyle of favorite celebrity then these factors also increase the sales of product.

Similarly, the value of correlation coefficient $r=-0.136$, is significant at 0.05 level of significance, examines that there is a negative relationship between favorite male celebrity and different advertisements persuade to purchase a product. It means that if influence of favorite male celebrity increases then means of advertisement (TV ads, websites and point of sales) decreases to persuade to purchase a product.

\section{Conclusions}

The purpose of the study is to examine the impact of celebrity endorsement on brand conscious consumers. The survey method is used and using simple random sampling data is collected. It is clearly obtained from the results that $83 \%$ respondents notice the quality of a brand, $62 \%$ respondents buy a product if their favorite celebrity is endorsing it, $68 \%$ think that celebrity advertisement helps in brand promotion, $53.2 \%$ agree that TV is the most powerful medium for advertisement, $46 \%$ buy only branded products, most people consider that social media (Facebook, Instagram, Twitter) influence people to purchase a product, $76 \%$ agree that product sales intensely rise because of celebrity advertisement, $83 \%$ agree that the purchasing power of consumers increases if brand owner offers discount on products, $92 \%$ believe that branded products are expensive, $76 \%$ agree that product sales intensely rise because of celebrity advertisement and 92\% believe that branded products are expensive. Furthermore, the value of correlation coefficient $(r=0.260)$ demonstrates a strong positive correlation between the celebrity advertisement and discount on products; that is, both affect the sales of items.

The analysis revealed that celebrity endorsement has a strong positive impact on brand conscious consumers as it's an implied device that can change people's buying behavior positively and students of different departments of GCWUS are becoming more and more conscious for branded products to show off their personality symbol. Celebrity advertisement also influences the brand conscious consumers, and high attractiveness of celebrities can help the consumers to remember the brand during shopping. Most people buy branded products even in high price because celebrity advertises that products and the products become easily known with exclusive brand image. It can be concluded that if people are aware of the brand and they have good brand perception, loyalty and association then automatically their insight about branded products will be stronger in minds and the brand will become the part of their buying behavior.

\section{Suggestion}

In the light of this study we can say that nowadays endorsing celebrities is a big marketing weapon to attract consumers and stay in consumers mind. In addi- 
tion, this study may be more accurate in the future by increasing sample size. As in this study respondents belonging to GCWUS are considered, so other studies can be conducted considering different target population.

\section{Limitations of the Study}

In present research sample size of 263 respondents is considered and it is very limited sample to generalize the results of the study; results may differ by using any other sample. Apart from this, it is a confined study to one university so by changing population, results may vary. As the research is conducted within one university, the perspective of consumers outside university is left unnoticed i.e. respondents are chosen who belong to university, people outside the university are ignored. Another limitation to this research is that most respondents are young female students; female students below the age of 25 and male students are not taken into consideration whose opinion regarding celebrity endorsement on brand conscious consumers would be different. In addition, all the brands and celebrities are not included in the questionnaire so student's opinion cannot be generalized.

\section{Conflicts of Interest}

The authors declare no conflicts of interest regarding the publication of this paper.

\section{References}

[1] Asraf, M., Naeem, M. and Shahzadi, M. (2017) Impact of Branding on Consumer Buying Behavior: An Evidence of Footwear Industry of Punjab, Pakistan. International Journal of Academic Research in Business and Social Sciences, 7, 2222-6990.

[2] Dissanayake, R. and Weerasiri (2017) The Impact of Perceived Effectiveness of Celebrity Endorsement on Perceived Brand Personaliy. Journal of Accounting and Marketing, 6, 2168-9601.

[3] Adam, M.A. and Hussain, N. (2017) Impact of Celebrity Endorsement on Consumers Buying Behavior. British Journal of Marketing Studies, 5, 79-121.

[4] Kaur, S. and Garg, A. (2016) Celebrity Endorsement and Buying Behavior: A Study of Panjab University Students. International Journal of Research, 4, 2394-3629.

[5] Nwokah, N.G. and Nwulu, C.S. (2015) The Influence of Celebrity Advertising on Consumer Brand Preference in Nigeria: Case Study of Chivita. Arts and Design Studies, 33, 2224-6061.

[6] Shehzad, U., Ahmed, S., Iqbal, K., Nawaz, M. and Usman, S. (2014) Influence of Brand Name on Consumer Choice and Decision. Journal of Business and Management, 16, 72-76. https://doi.org/10.9790/487X-16637276

[7] Malik, M.E., Ghafoor, M.M., Iqbal, H.K., Ali, Q., Hunbal, H., Noman, M. and Ahmed, B. (2013) Impact of Brand Image and Advertisement on Consumer Buying Behavior. World Applied Sciences Journal, 23, 117-122.

[8] Miller, F.M. and Allen, C.T. (2012) How Does Celebrity Meaning Transfer? Investigating the Process of Meaning Transfer with Celebrity Affiliates and Mature Brands. Journal of Consumer Psychology, 22, 443-452. 
https://doi.org/10.1016/j.jcps.2011.11.001

[9] Esangbedo, R. (2011) The Impact of Celebrity Endorsement on the Consumer Buying Behavior of Rowan University Students Age 18-24. Theses and Dissertations, 88.

[10] Zeb, H., Rashid, K. and Javeed, M.B. (2011) Influence of Brands on Female Consumer's Buying Behavior in Pakistan. International Journal of Trade, Economics and Finance, 2, 225-231.

[11] Khasawneh, K. and Hasouneh, A.B.I. (2010) The Effect of Familiar Brand Names on Consumers Behaviors: A Jordanians Perspective. International Research Journal of Finance and Economics, 43, 33-57.

[12] Spry, A., Pappu, R. and Cornwell, T.B. (2011) Celebrity Endorsement, Brand Credibility and Brand Equity. European Journal of Marketing, 45, 882-909. https://doi.org/10.1108/03090561111119958

[13] Yamane, T. (1967) Statistics: An Introductory Analysis. Harper and Row, New York. 


\section{Appendix}

\section{Impact of Celebrity Endorsement on Brand Conscious Consumer.}

1. Which is your favorite female celebrity?
$\square$ Ayeza khan
$\square$ Mahira Khan
$\square$ Aiman khan
Sajal Ali

2. Which is your favorite male celebrity?
$\square$ Shahid Afridi
$\square$ Fawad Khan
Faisal Qureshi
Fahad Mustafa

3. Which brand do you like the most?
$\square \mathrm{J}$.
$\square$ Stylo
Metro
$\square$ ECS

4. What makes you notice a brand?
$\square$ Quality
$\square$ Price
Endorsing Celebrity
Advertisement

5. Would you buy a brand if your favorite celebrity is endorsing it?
$\square$ Strongly Agree
Agree
Neutral
Disagree
Strongly Disagree

6. Does celebrity advertisement help in brand promotion?
$\square$ Yes
$\square$ No
$\square$ Not sure

7. What are the sources of product information?
$\square$ TV Ads
$\square$ Websites
$\square$ Favorite Celebrity
Point of sales

8. Do you buy only Branded products?
$\square$ Yes
$\square$ No
Yes, Always
Rarely

9. In which things you are more interested and want to buy?
$\square$ Footwears
Clothes
$\square$ Bags
Perfumes

10. What means of advertisement persuades you to purchase a product?
$\square \mathrm{TV}$
$\square$ Magazines
$\square$ Social Media
$\square$ Point of sales

11. What do you like in your favorite celebrity?
$\square$ Hair
$\square$ Look
$\square$ Lifestyle
All of them

12. How long you can use branded products?
$\square$ One Year
$\square$ Two Years
$\square$ For a Long Time

13. Do you think that products which are advertised by celebrities are reliable?
$\square$ Yes
$\square$ No
$\square$ Not sure

14. Do you think that some product sales dramatically rise because of celebrity advertisement?
$\square$ Yes
$\square$ No

15. If a brand owner offers discount on products, then the purchasing power of consumer is?
$\square$ Increased
$\square$ Decreased
$\square$ Normal

16. Do you think that branded products are expensive?
$\square$ Yes
$\square$ No 